\title{
PENGARUH PROGRAM MARKETING COMMUNICATION TERHADAP KEPUTUSAN BERKUNJUNG DI TAMAN NASIONAL UJUNG KULON (Survei pada Wisatawan yang Berkunjung ke Taman Nasional Ujung Kulon)
}

\author{
Novarin Nurjanah \\ Bagja Waluya \\ Manajemen Pemasaran Pariwisata FPIPS UPI
}

\begin{abstract}
Banten is one province in Indonesia which has a variety of objects and the potential tourism. One of the tourist area is Ujung Kulon National Park. Ujung Kulon National Park is a kind of ecological tourism (ecotourism) that located in Pandeglang. This national park is very well known to foreign tourists and domestic tourists, primarily as a place of preservation of the Javan rhino (one-horned rhino and buffalo). However, tourist arrivals Ujung Kulon National Park in 2010 has decreased, therefore necessary to conduct research on aspects related to increasing the number of visits. including through programs conducted by the marketing communication manager Ujung Kulon National Park. Based on this, the researcher interested to conduct research The Influence of Marketing Communication Programs towards Visiting Decision in Ujung Kulon National Park. The problem of this study are 1). How the idea of marketing communication programs, 2). How the idea of the decision to visit, 3). How does influence marketing communication programs to the visiting decision. This study aims to obtain marketing communication description, visiting decision description and the influence of marketing communications programs to the visiting decision. The technical analysis of the data in this study is used the analysis of the path (path analysis) with a sampling technique is systematic random sampling of 100 respondents. The results of this study indicate that marketing communication programs have a significant influence on the decision to visit. Greatest effect is obtained through advertising and the smallest effect is obtained through the event and experience. This is because advertising is a means of promotion through various media such as print and electronic media that can provide more information to tourists. Suggestion for managers Ujung Kulon National Park, should further develop marketing programs through organized events and improve the quality of tourist attractions as well as provide information best time to visit the National Park Ujung Kulon.
\end{abstract}

Key words: Marketing Communication, Visiting Decision

\section{PENDAHULUAN}

\subsection{Latar Belakang}

Berikut ini adalah data jumlah

kunjungan wisatawan ke Taman Nasional

Ujung Kulon sampai dengan Tahun 2010 .

TABEL 1.1

DATA JUMLAH KUNJUNGAN WISATAWAN DI TAMAN NASIONAL UJUNG KULON TAHUN 2005- 2010

\begin{tabular}{|c|c|c|c|c|c|c|}
\hline \multirow{2}{*}{ TAHUN } & \multicolumn{3}{|c|}{ KUNJUNGAN WISATAWAN } & \multirow{2}{*}{ TOTAL } & \multirow{2}{*}{$(\%)$} \\
\cline { 2 - 6 } & WISNUS & $(\%)$ & WISMAN & $(\%)$ & & \\
\hline $\mathbf{2 0 0 5}$ & 2.573 & - & 622 & - & 3.195 & - \\
$\mathbf{2 0 0 6}$ & 1.907 & $-25,88$ & 461 & $-24,88$ & 2.368 & $\mathbf{- 3 4 , 9 6 \%}$ \\
$\mathbf{2 0 0 7}$ & 1.813 & $-4,92$ & 472 & 2,38 & 2.285 & $\mathbf{- 3 , 6 3 \%}$ \\
$\mathbf{2 0 0 8}$ & 1.834 & 1,15 & 677 & $-41,31$ & 2.511 & $\mathbf{9 , 0 \%}$ \\
$\mathbf{2 0 0 9}$ & 2.940 & 60,30 & 552 & $-18,46$ & 3.492 & $\mathbf{2 , 8 6 \%}$ \\
$\mathbf{2 0 1 0}$ & 2.194 & $-25,37$ & 257 & $-53,44$ & 2.451 & $\mathbf{- 2 9 , 8 1 \%}$ \\
\hline JUMLAH & 18.524 & - & 3.804 & - & 22.328 & - \\
\hline
\end{tabular}


Sumber : Balai Taman Nasional Ujung Kulon 2011

Berdasarkan Tabel $1.1 \mathrm{di}$ atas dapat dilihat bahwa kunjungan wisatawan mengalami penurunan kunjungan pada tahun 2005 sebesar $-34,96 \%$ sampai dengan tahun 2007 sebesar $-3,63 \%$, namun Tahun 2008 kunjungan wisatawan berangsur membaik sehingga tahun 2009 mengalami pertumbuhan sebanyak 3.492 atau sebesar 2,86\%. Namun pada tahun 2010 kunjungan wisatawan mengalami penurunan kembali yaitu sebanyak 2.451 atau sebesar $-29,81 \%$.

Penurunan tersebut diakibatkan oleh beberapa faktor yaitu karena kurang optimalnya promosi yang dilakukan oleh pihak pengelola Taman Nasional Ujung Kulon, selain itu iklim/cuaca yang kurang mendukung untuk berkunjung, tidak tersedianya transportasi yang lengkap dan memadai, serta infrastruktur jalan yang kurang baik. Hal tersebut merupakan faktor yang tidak dapat dipisahkan untuk mendukung terciptanya keputusan berkunjung wisatawan ke Taman Nasional Ujung Kulon.

Fenomena tersebut dapat menjadi acuan pihak pengelola Taman Nasional Ujung Kulon untuk mengambil tindakan atau keputusan, agar keputusan berkunjung di Taman Nasional Ujung Kulon dapat meningkat kembali. Salah satu cara yang dilakukan oleh pihak pengelola Taman Nasional Ujung Kulon untuk meningkatkan kembali tingkat keputusan berkunjung wisatawan, yaitu dengan melakukan strategi promosi.

Strategi promosi yang dilakukan oleh Taman Nasional Ujung Kulon untuk meningkatkan kunjungan jumlah wisatawan adalah dengan menggunakan komunikasi pemasaran (Marketing Communication). Menurut Kotler \& Keller (2009 : 472) Marketing Communication terdiri dari Advertising, Sales Promotion, Event and Experience, Public Relations and publicity, Direct Marketing, Interactive Marketing, Word-of-mouth marketing dan Personal Selling.

Berikut adalah data mengenai strategi promosi yang dilakukan Taman Nasional Ujung Kulon.
TABEL 1.2

STRATEGI PROMOSI TAMAN NASIONAL UJUNG KULON 2011

\begin{tabular}{|c|c|c|}
\hline No & $\begin{array}{c}\text { Marketing } \\
\text { Communication }\end{array}$ & Keterangan \\
\hline 1 & Advertising & $\begin{array}{l}\text { Media Cetak : } \\
\text { Brosur, leaflet, } \\
\text { booklet, stiker } \\
\text { Media Elektronik : } \\
\text { TV, internet }\end{array}$ \\
\hline 2 & $\begin{array}{l}\text { Event and } \\
\text { experience }\end{array}$ & Pameran \\
\hline 3 & $\begin{array}{l}\text { Public Relations } \\
\text { and publicity }\end{array}$ & $\begin{array}{l}\text { News : Bulletin } \\
\text { Media identity : } \\
\text { Logo }\end{array}$ \\
\hline 4 & $\begin{array}{l}\text { Interactive } \\
\text { Marketing }\end{array}$ & Website \\
\hline
\end{tabular}

Sumber : Balai Taman Nasional Ujung Kulon 2011

Berdasarkan Tabel 1.2 dapat dilihat bahwa pihak pengelola Taman Nasional Ujung Kulon telah melakukan strategi promosi baik melalui Advertising seperti pembuatan dan penyebaran brosur, leaflet, stiker dan booklet. Melalui Event and experience dengan mengikuti berbagai pameran. Pulic Relations and publicity seperti menciptakan berita melalui bulletin dan memiliki media identitas, dengan adanya logo Taman Nasional Ujung Kulon dan seragam yang dikenakan oleh pengelola objek tersebut. Interactive Marketing dengan membuat website yang menjelaskan berbagai informasi mengenai Taman Nasional Ujung Kulon.

Melalui strategi komunikasi pemasaran diharapkan dapat mempengaruhi keputusan wisatawan untuk berkunjung ke Taman Nasional Ujung Kulon. Motivasi dari pengunjung dapat menentukan tipe produk wisata yang dibutuhkan oleh wisatawan yang pada akhirnya akan menentukan keputusan wisatawan dalam memilih objek wisata mana yang akan dikunjungi. Suatu destinasi akan dapat menarik banyak wisatawan jika tempat wisata tersebut memiliki keindahan, terkelola dengan baik dan memberikan kenyamanan kepada wisatawan yang datang. Semakin baik pengelolaan objek wisata maka akan dapat menarik banyak wisatawan untuk mengunjungi objek wisata tersebut.

Menurut Kotler \& Keller (2009 : 510) Marketing Communications are the means by which firms attempt to inform, persuade, and remind consumersn directly or indirectly about the product and brand that 
they sell. Yang artinya bahwa marketing communication merupakan usaha perusahaan untuk menginformasikan, mengajak, mengingatkan konsumen baik secara langsung maupun tidak langsung tentang produk dan merek yang mereka jual.

Strategi Marketing Communication ini diharapkan dapat memberikan motivasi kepada para wisatawan sehingga dapat melakukan kunjungan ke Taman Nasional Ujung Kulon. Karena komunikasi pemasaran merupakan konsep pemasaran yang dapat menghubungan para pengunjung atau calon pengunjung melalui berbagai elemen dari komunikasi pemasaran yang pada akhirnya dapat menciptakan keputusan berkunjung wisatawan pada suatu objek.

Berdasarkan latar belakang di atas maka perlu diadakan suatu penelitian tentang "Pengaruh Program Marketing Communication Terhadap Keputusan Berkunjung di Taman Nasional Ujung Kulon". (Survei dilakukan pada wisatawan yang berkunjung ke Taman Nasional Ujung Kulon)".

\subsection{Rumusan Masalah}

Berdasarkan Latar belakang di atas, maka rumusan masalah dari penelitian ini adalah sebagai berikut:

1. Bagaimana gambaran mengenai Marketing Communication di Taman Nasional Ujung Kulon?

2. Bagaimana gambaran mengenai Keputusan Berkunjung di Taman Nasional Ujung Kulon?

3. Bagaimana pengaruh Marketing Communication terhadap Keputusan Berkunjung di Taman Nasional Ujung Kulon?

\subsection{Tujuan Penelitian}

Berdasarkan rumusan masalah di atas, maka tujuan penulis mengadakan penelitian ini adalah sebagai berikut:

1. Untuk memperoleh gambaran mengenai Marketing Communication di Taman Nasional Ujung Kulon.

2. Untuk memperoleh gambaran mengenai Keputusan Berkunjung di Taman Nasional Ujung Kulon.

3. Untuk mengetahui pengaruh Marketing Communication terhadap Keputusan Berkunjung di Taman Nasional Ujung Kulon.

\subsection{Kegunaan Penelitian}

Hasil penelitian ini diharapkan dapat bermanfaat, baik secara teoritis Maupun praktis, sebagai berikut:

\subsubsection{Kegunaan Teoritis}

Secara teoritis diharapkan hasil penelitian ini dapat memperluas kajian ilmu manajemen pemasaran pariwisata, khususnya marketing communication dan memberikan masukan pada peneliti dalam mengembangkan ilmu manajemen pemasaran pariwisata.

\subsubsection{Kegunaan Praktis}

Hasil penelitian ini diharapkan dapat memberi masukan bagi pihak pengelola Taman Nasional Ujung Kulon dalam memasarkan objek wisata tersebut sehingga kunjungan wisatawan yang berkunjung ke Taman Nasional Ujung Kulon mengalami peningkatan. Penelitian ini juga dapat dijadikan sebagai masukan kepada pihakpihak lain terutama objek-objek wisata sejenis agar dapat memasarkan objek wisata tersebut untuk meningkatkan kunjungan wisatawan.

\section{KERANGKA PEMIKIRAN DAN}

\section{HIPOTESIS}

\subsection{Kajian Pustaka}

Pemasaran Pariwisata (Tourism Marketing) adalah suatu sistem dan koordinasi yang dilaksanakan sebagai suatu kebijakan bagi perusahaan-perusahaan yang bergerak di bidang kepariwisataan, baik milik swasta maupun pemerintah, dalam ruang lingkup lokal, regional, nasional dan internasional untuk dapat mencapai kepuasan wisatawan dengan memperoleh keuntungan yang wajar. (Yoety 1990:30).

\section{Pengertian Bauran Promosi}

Strategi pemasaran dapat terpenuhi dengan penyediaan suatu sarana yang disebut marketing mix. Marketing mix ini merupakan inti dari sistem pemasaran perusahaan. Menurut Ratih Hurriyati (2008) menyatakan bahwa bauran pemasaran jasa sebagai berikut :

"Marketing mix merupakan unsurunsur pemasaran yang saling terkait, dibaurkan, diorganisir, dan digunakan dengan tepat, sehingga perusahaan dapat mencapai tujuan pemsaran dengan efektif, sekaligus memuaskan kebutuhan dan keinginan konsumen". 
Marketing mix merupakan seperangkat alat pemasaran yang digunakan perusahaan untuk terus-menerus mencapai tujuan pemasarannya di pasar sasaran". (Philip Kotler, 2009:101). McCarthy dalam Kotler dan Keller (2009:63) mengklasifikasikan menjadi empat kelompok besar, yang disebut 4P tentang pemasaran yaitu Produk (product), Harga (price), Tempat (place), dan Promosi (promotion).

Konsep hospitality marketing mix diperluas menjadi 8P, dengan penambahan people, packaging, partnership dan programming menurut Morrison (2006 : 219) sehingga secara keseluruhan hospitality marketing mix terdiri dari $8 \mathrm{P}$, yaitu :

\section{Product}

Merupakan keseluruhan konsep objek atau proses yang memberikan sejumlah nilai kepada wisatawan.

2. Price

Harga merupakan element penting dalam marketing mix, karena harga merupakan faktor yang dapat menarik wisatawan untuk berkunjung ke suatu destinasi.

3. Place

Place merupakan hal pokok dalam industri pariwisata, karena wisatawan harus melakukan perjalanan menuju destinasi untuk mengkonsumsi produk wisata.

4. Promotion

Merupakan upaya untuk meningkatkan permintaan melalui pertimbangan keputuhan, nilai dan sikap pasar, atau segmen target pasar.

5. People

Merupakan penyedia jasa yang melayani wisatawan. People sedikitnya memiliki tiga hal yaitu service personnel, the tourist themselves, dan local resident.

6. Packaging

Packaging berarti mengelompokan dua elemen atau lebih dari tourism experience ke dalam satu produk.

7. Programming

Programming memiliki kaitan dengan packaging yang melibatkan event special aktivitas atau program suatu produk untuk membuatnya lebih beranekaragam dan menarik

8. Partnership

Suatu hubungan yang dijalin oleh bisnis sejenis maupun bisnis tidak sejenis yang menciptakan benefit bagi pihak-pihak tersebut.

\section{Pengertian Marketing Communication}

Menurut Kotler \& Keller (2009 : 510)

Marketing Communications are the means by which firms attempt to inform, persuade, and remind consumersn directly or indirectly about the product and brand that they sell.

Dalam proses komunikasi terdapat dua elemen yang merupakan bagian besar dalam komunikasi yaitu pengirim (sender) dan penerima (receiver). Dua elemen lain yang merupakan alat komunikasi yaitu pesan (message) dan media serta 4 elemen lainnya yang merupakan fungsi komunikasi yaitu encoding (memberi kode), decoding (mengartikan kode), response, feedback dan noise. Pengirim memberikan kode-kode melalui message dengan cara yang sama seperti bagaimana penerima mengartikan kode-kode yang terdapat dalam message.

Kotler \& Keller menyebutkan dalam buku Marketing Management (2009 : 472) bahwa Marketing Communication terdiri dari delapan elemen yaitu Advertising, Sales Promotion, Event and experience, Public Relation and publicity, Direct marketing, Interactive marketing, Word-of-mouth marketing dan Personal Selling.

Marketing communication yang terdiri dari beberapa dimensi memiliki peranan penting dalam mengkomunikasikan produk pariwisata sehingga dapat memberikan pengaruh yang baik pada pertumbuhan kunjungan wisatawan di sebuah daya tarik wisata atau perusahaan.

\section{Pengertian Keputusan Berkunjung}

Kotler dan Keller (2009:208) menyatakan bahwa, keputusan berkunjung adalah tahap saat wisatawan juga mungkin membentuk niat untuk melakukan kunjungan yang paling disukai, dimana keputusan wisatawan untuk memodifikasi, menunda, atau menghindar sangat dipengaruhi oleh resiko yang dirasakan. Menurut Kotler \& Keller (2009 : 248) ada enam keputusan yang dilakukan oleh wisatawan, modifikasi melalui teori keputusan pembelian yang dilakukan oleh konsumen yaitu :

1. Pemilihan Produk/Jasa

Tahapan wisatawan dalam menentukan produk yang ditawarkan, dan diantaranya dipengaruhi oleh kualitas dan variasi produk tersebut. Tahapan ini wisatawan dalam mengambil keputusan berkunjung atau menggunakan uangnya untuk tujuan yang lain dalam hal ini perusahaan harus 
memusatkan perhatiannya kepada orangorang yang berkunjung serta alternatif yang mereka pertimbangkan.

2. Pemilihan Merek

Tahapan wisatawan sebelum memutuskan berkunjung yang dipengaruhi oleh merek dan kemenarikan objek tersebut. Pada tahapan ini wisatawan harus memutuskan merek mana yang akan dibeli. Setiap merek memiliki perbedaan-perbedaan tersendiri. Dalam hal ini perusahaan harus mengetahui bagaimana wisatawan memilih sebuah merek.

3. Pemilihan Perantara/Saluran Pemesanan Tahapan wisatawan sebelum memutuskan berkunjung yang dipengaruhi oleh bagaimana wisatawan memilih saluran pemesanan. Pada tahapan ini wisatawan harus mengambil keputusan tentang perantara, untuk keputusan berkunjung setiap wisatawan berbeda-beda dalam hal menentukan perantara bisa dikarenakan fitur lokasi yang dilihat, harga yang murah, kenyamanan, dan lain sebagainya.

4. Pemilihan Waktu Berkunjung

Tahapan wisatawan sebelum memutuskan berkunjung yang dipengaruhi oleh waktu kapan wisatawan menentukan waktu untuk berkunjung. Pada tahapan ini keputusan wisatawan untuk berkunjung dalam waktu bisa berbeda-beda misalkan: ada yang tiap hari, satu minggu, dua minggu sekali sesuai dengan keinginan wisatawan.

5. Pemilihan Jumlah Pemesanan

Tahapan wisatawan sebelum memutuskan berkunjung yang dipengaruhi oleh jumlah pemesanan yang dilakukan oleh wisatawan. Pada tahapan ini wisatawan dapat mengambil keputusan tentang seberapa banyak objek wisata yang akan dikunjungi. Keputusan berkunjung yang dilakukan mungkin lebih dari satu dalam hal ini perusahaan harus mempersiapkan banyak pilihan sesuai dengan keinginan yang berbeda-beda dari pada wisatawan.

6. Metode Pembayaran

Tahapan wisatawan sebelum memutuskan berkunjung yang dipengaruhi oleh bagaimana kemudahan dalam membayar. Tahapan ini merupakan tahapan akhir dalam model keputusan berkunjung yaitu dimana wisatawan dalam melakukan keputusan berkunjung dapat memilih metode pembayaran, apakah dengan tunai (cash) atau kredit (credit card).

\subsection{Kerangka Pemikiran}

Berdasarkan kajian teoritis maka kerangka pemikiran sangat dibutuhkan sebagai alur berpikir sekaligus sebagai landasan untuk menyusun hipotesis penelitian. Kerangka pemikiran disusun berdasarkan pendapat para ahli yang menerangkan bahwa dalam penelitian ini terdapat dua variabel yaitu satu variabel bebas marketing communication (X) yang terdiri dari advertising, event and experience, public relations and publicity, dan interactive marketing dan satu variabel terikat yaitu keputusan berkunjung (Y) yang terdiri dari pemilihan produk, pemilihan merek, pemilihan perantara, dan pemilihan waktu berkunjung.

Berdasarkan pemaparan tersebut paradigma penelitian ini diperlihatkan pada Gambar 2.1 sebagai berikut:

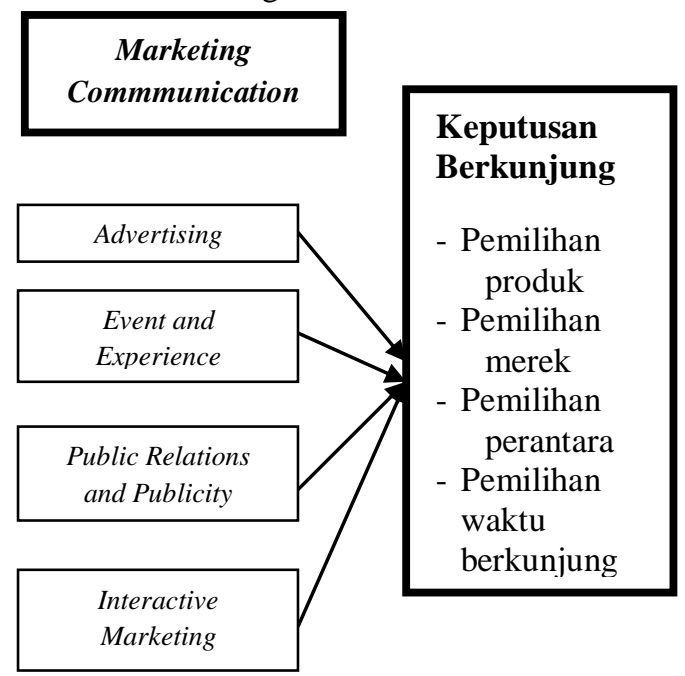

Keterangan: $=$ Pengaruh kausalitas antar variabel

\section{GAMBAR 2.1 KERANGKA PEMIKIRAN}

\subsection{Hipotesis}

Hipotesis merupakan jawaban sementara terhadap masalah penelititan yang dibangun berdasarkan kerangka teoritis tertentu yang kebenarannya perlu diuji secara empiris. Hipotesis merupakan jawaban sementara terhadap rumusan masalah penelitian menurut Sugiyono (2008:51).

Penelitian dalam menyusun hipotesis didukung oleh beberapa premis sebagai berikut:

1. Daniel Axelsson dan Hendrik
Nordberg (2005) 
Marketing Communication message, such as advertising, sales promotion, direct marketing, public relation, special event or trade shows all seek to do are thing, to place bits of information in the consumer's mind, to influence later decision.

2. Caratina Olander dan Christer Sehlin (2000)

Integrated marketing communication can wrap communication around customer and help them move though the various stages of buying process.

Berdasarkan premis-premis di atas, maka peneliti mengemukakan hipotesis dalam penelitian ini yaitu terdapat pengaruh yang signifikan antara marketing communication yang terdiri dari advertising, event and experience, public relations and publicity dan interactive marketing terhadap keputusan berkunjung.

\section{OBJEK DAN METODE PENELITIAN}

\subsection{Metode yang digunakan}

Jenis penelitian ini adalah deskriptif dan verifikatif yang dilaksanakan melalui pengumpulan data di lapangan, maka metode penelitian yang digunakan adalah metode deskriptif survey dan metode explanatory survey.

Berdasarkan jenis penelitian di atas, maka metode penelitian yang digunakan adalah metode deskriptif survey dan explanatory survey. Menurut Ker Linger dalam Sugiyono (2008:7) bahwa "metode deskriptif survey dan explanatory survey merupakan metode penelitian yang dilakukan pada populasi besar maupun kecil, tetapi data yang dipelajari adalah data dari sampel yang diambil dari populasi tersebut, sehingga ditemukan deskripsi dan hubungan-hubungan antar variabel". Pada penelitian yang menggunakan metode ini informasi dari sebagian populasi dikumpulkan langsung ditempat kejadian dengan tujuan untuk mengetahui pendapat dari sebagian populasi terhadap objek yang sedang diteliti.

\subsection{Populasi, Sampel dan Teknik Sampel}

Populasi pada penelitian ini adalah wisatawan yang berkunjung ke Taman Nasional Ujung Kulon yang berjumlah 2.451 orang pada tahun 2010. Sampel dalam penelitian ini adalah sebagian dari populasi penelitian, yaitu sebagian wisatawan di
Kawasan Taman Nasional Ujung Kulon dengan jumlah sebesar 100 sampel. Teknik sampling yang digunakan dalam penelitian ini adalah teknik systematic random sampling. Karena populasinya dianggap homogen dan dapat digunakan tanpa pengetahuan mengenai bingkai sampling. Menurut Harun Al rasyid (1994 : 66) sampling sistematik ini memiliki kelebihan, yaitu bisa dilakukan sekalipun tidak ada kerangka sampling

\subsection{Operasional Variabel}

Variabel-variabel yang digunakan dalam penelitian ini terdiri dari:

1. Variabel bebas (variabel X), yang dalam penelitian ini adalah marketing communication (X) dengan sub variabelnya advertising, event and experience, public relations and publicity, dan interactive marketing.

2. Variabel terikat (variabel Y), yang dalam penelitian ini keputusan berkunjung (Y) yang terdiri dari pemilihan produk, pemilihan merek, pemilihan saluran pembelian, pemilihan waktu dan metode pembayaran.

\subsection{Jenis dan Sumber Data}

Lebih jelasnya mengenai data dan sumber data yang digunakan dalam penelitian, maka peneliti mengumpulkan dan menyajikan data dalam Tabel 3.1 berikut:

TABEL 3.1

JENIS DAN SUMBER DATA

\begin{tabular}{|c|c|c|c|}
\hline $\begin{array}{l}\mathbf{N} \\
\text { o. }\end{array}$ & Jenis Data & $\begin{array}{c}\text { Sumber } \\
\text { Data }\end{array}$ & $\begin{array}{c}\text { Kategori } \\
\text { Data }\end{array}$ \\
\hline 1. & $\begin{array}{l}\text { Statistik } \\
\text { Jumlah } \\
\text { Kunjungan } \\
\text { Wisatawan } \\
\text { Mancanegar } \\
\text { a Ke } \\
\text { Indonesia } \\
\text { Tahun 2004- } \\
2010\end{array}$ & $\begin{array}{l}\text { Pusat } \\
\text { Pengelolaa } \\
\text { n Data dan } \\
\text { Sistem } \\
\text { Jaringan } \\
\text { (P2DSJ) } \\
\text { dan Badan } \\
\text { Pusat } \\
\text { Statistik } \\
\text { (BPS) } \\
\text { 2011 }\end{array}$ & $\begin{array}{c}\text { Data } \\
\text { Sekunder }\end{array}$ \\
\hline 2. & $\begin{array}{l}\text { Statistik } \\
\text { Jumlah } \\
\text { Kunjungan } \\
\text { Wisatawan } \\
\text { Nusantara } \\
\text { Tahun 2004 } \\
\text { - } 2010\end{array}$ & $\begin{array}{l}\text { BPS dan } \\
\text { Kementeri } \\
\text { an Budaya } \\
\text { dan } \\
\text { Pariwisata } \\
\text { (Kemenbu } \\
\text { dpar) 2011 }\end{array}$ & $\begin{array}{c}\text { Data } \\
\text { Sekunder }\end{array}$ \\
\hline
\end{tabular}




\begin{tabular}{|c|c|c|c|}
\hline 3. & $\begin{array}{l}\text { Data Jumlah } \\
\text { Kunjungan } \\
\text { Wisatawan } \\
\text { ke Provinsi } \\
\text { Banten pada } \\
\text { Tahun 2005- } \\
2010\end{array}$ & $\begin{array}{l}\text { Dinas } \\
\text { Budaya } \\
\text { dan } \\
\text { Pariwisata } \\
\text { Provinsi } \\
\text { Banten } \\
2011\end{array}$ & $\begin{array}{c}\text { Data } \\
\text { Sekunder }\end{array}$ \\
\hline 4. & $\begin{array}{l}\text { Data Jenis } \\
\text { Objek } \\
\text { Wisata yang } \\
\text { diminati } \\
\text { Wisatawan } \\
\text { Mancanegar } \\
\text { a di Provinsi } \\
\text { Banten }\end{array}$ & $\begin{array}{l}\text { Neraca } \\
\text { Satelit } \\
\text { Pariwisata } \\
\text { Daerah } \\
\text { Banten } \\
2009\end{array}$ & $\begin{array}{c}\text { Data } \\
\text { Sekunder }\end{array}$ \\
\hline 5. & $\begin{array}{l}\text { Data Jenis } \\
\text { Objek } \\
\text { Wisata yang } \\
\text { diminati } \\
\text { Wisatawan } \\
\text { Nusantara di } \\
\text { Provinsi } \\
\text { Banten }\end{array}$ & $\begin{array}{l}\text { Neraca } \\
\text { Satelit } \\
\text { Pariwisata } \\
\text { Daerah } \\
\text { Banten } \\
2009\end{array}$ & $\begin{array}{c}\text { Data } \\
\text { Sekunder }\end{array}$ \\
\hline 6. & $\begin{array}{l}\text { Data Jumlah } \\
\text { Kunjungan } \\
\text { Wisatawan } \\
\text { Nusantara } \\
\text { dan } \\
\text { Mancanegar } \\
\text { a di Taman } \\
\text { Nasional } \\
\text { Ujung Kulon } \\
\text { 2005-2010 }\end{array}$ & $\begin{array}{l}\text { Balai } \\
\text { Taman } \\
\text { Nasional } \\
\text { Ujung } \\
\text { Kulon } \\
2011\end{array}$ & $\begin{array}{c}\text { Data } \\
\text { Sekunder }\end{array}$ \\
\hline 7. & $\begin{array}{l}\text { Tanggapan } \\
\text { responden } \\
\text { mengenai } \\
\text { Marketing } \\
\text { Communicat } \\
\text { ion }\end{array}$ & $\begin{array}{l}\text { Wisatawa } \\
\mathrm{n} \\
\text { Nusantara } \\
\text { di } \\
\text { Kawasan } \\
\text { Taman } \\
\text { Nasional } \\
\text { Ujung } \\
\text { Kulon } \\
\end{array}$ & $\begin{array}{l}\text { Data } \\
\text { Primer }\end{array}$ \\
\hline 8. & $\begin{array}{l}\text { Tanggapan } \\
\text { responden } \\
\text { mengenai } \\
\text { Keputusan } \\
\text { Berkunjung }\end{array}$ & $\begin{array}{l}\text { Wisatawa } \\
\mathrm{n} \\
\text { Nusantara } \\
\text { di } \\
\text { Kawasan } \\
\text { Taman } \\
\text { Nasional } \\
\text { Ujung } \\
\text { Kulon }\end{array}$ & $\begin{array}{l}\text { Data } \\
\text { Primer }\end{array}$ \\
\hline
\end{tabular}

Sumber : Pengolahan Data 2012

\subsection{Pengujian Hipotesis}

Teknik analisis data yang digunakan dalam penelitian ini adalah path analysis (analisis jalur). Analisis jalur bertujuan untuk menerangkan besarnya pengaruh langsung dan tidak langsung dair satu atau lebih variabel sebagai variabel penyebab terhadap satu atau lebih variabel lainnya sebagai variabel akibat. Adapun untuk pengolahan data dapat dilakukan dengan bantuan program SPSS 17 for Windows.

Berikut ini diagram sub hipotesis yang menyatakan pengaruh sub-variabel independen terhadap variabel dependen, seperti dapat dilihat pada gambar berikut :

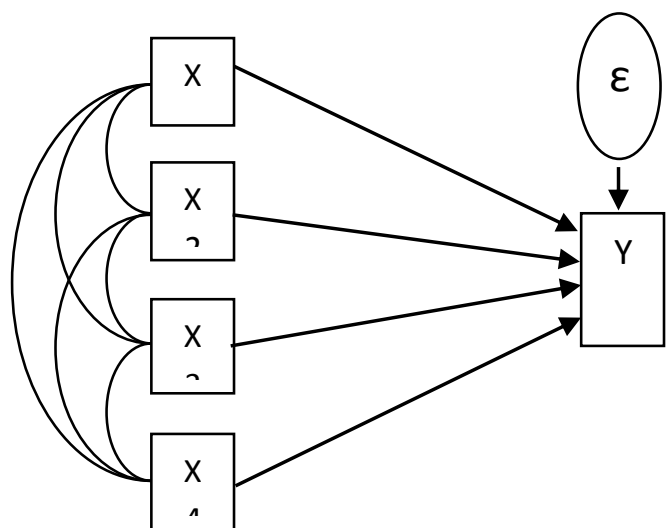

Keterangan:

$\mathbf{X}_{\mathbf{1}}=$ Advertising

$\mathbf{X}_{\mathbf{2}}=$ Event and Experience

$\mathbf{X}_{\mathbf{3}}=$ Public Relation and Publicity

$\mathbf{X}_{\mathbf{4}}=$ Interactive Marketing

$\mathbf{Y}=$ Keputusan Berkunjung

$\boldsymbol{\varepsilon}=$ Epsilon (Variabel Lain)

\section{HASIL PENELITIAN DAN PEMBAHASAN}

\subsection{Profil Kawasan Wisata Taman}

Nasional Ujung Kulon

Taman Nasional Ujung Kulon terletak di Kabupaten Pandeglang, Provinsi Banten. Secara geografis terletak di koordinat $6^{\circ} 30^{\prime}$ $34^{\prime \prime}-6^{\circ} 52^{\prime} 17^{\prime \prime}$ LS dan $102^{\circ} 2^{\prime} 32^{\prime}-102^{\circ}$ $37^{\prime} 37^{\prime}$ BT, kawasan seluas 120.551 ha, meliputi Kawasan Taman Nasional Ujung Kulon yang dikelola dengan sistem zonasi dengan sistem pembagian meliputi : zona inti (37.150 ha), zona rimba (77.295 ha), zona pemanfaatan intensif (1.096 ha), zona pemanfaatan tradisional (1.810 ha), dan zona rehabilitasi (3.200 ha).

Kawasan Ujung Kulon ditetapkan sebagai taman nasional dengan Surat Keputusan Menteri Kehutanan Nomor 284/Kpts-II/1992 yang sebelumnya pada tahun 1980 dideklarasikan oleh Menteri Pertanian sebagai "Lima Taman Nasional Pertama di Indonesia". Komisi Warisan Alam Dunia UNESCO/Perserikatan Bangsa- 
bangsa (1992) menetapkan kawasan Taman Nasional Ujung Kulon sebagai World Heritage Site dengan Surat No. SC/Eco/5867.2.409 karena dinilai mempunyai sumber daya alam yang bernilai penting yang tidak dimiliki oleh kawasan lain di dunia.

\section{a. Rekapitulasi Hasil Tanggapan Wisatawan Terhadap Marketing Communication di Taman Nasional Ujung Kulon}

Rekapitulasi mengenai hasil tanggapan wisatawan terhadap marketing communication di Taman Nasional Ujung Kulon dapat dilihat pada tabel 4.1 berikut ini:

TABEL 4.1

REKAPITULASI HASIL TANGGAPAN WISATAWAN TERHADAP MARKETING COMMUNICATIONDI TAMAN NASIONAL UJUNG KULON

\begin{tabular}{|c|c|c|c|c|}
\hline $\begin{array}{c}\mathrm{N} \\
\mathrm{o}\end{array}$ & Sub Variabel & $\begin{array}{c}\text { Tot } \\
\text { al } \\
\text { Sko } \\
\mathrm{r}\end{array}$ & $\begin{array}{c}\text { Skor } \\
\text { Rata- } \\
\text { rata }\end{array}$ & $\%$ \\
\hline 1 & Advertising & $\begin{array}{c}272 \\
7\end{array}$ & $\begin{array}{c}340,8 \\
8\end{array}$ & $\begin{array}{c}25,3 \\
6\end{array}$ \\
\hline 2 & $\begin{array}{c}\text { Event and } \\
\text { Experience }\end{array}$ & $\begin{array}{c}131 \\
1\end{array}$ & 327,8 & $\begin{array}{c}24,3 \\
9\end{array}$ \\
\hline 3 & $\begin{array}{c}\text { Public Relation } \\
\text { and Publicity }\end{array}$ & 635 & 317,5 & $\begin{array}{c}23,6 \\
2\end{array}$ \\
\hline 4 & $\begin{array}{c}\text { Interactive/Inte } \\
\text { rnet Marketing }\end{array}$ & $\begin{array}{c}107 \\
4\end{array}$ & 358 & $\begin{array}{c}26,6 \\
3\end{array}$ \\
\hline \multicolumn{7}{|c|}{ Total } & $\begin{array}{c}574 \\
7\end{array}$ & 1344, & 18 & 100 \\
\hline
\end{tabular}

Sumber: Hasil Pengolahan Data 2012

Berdasarkan Tabel 4.1 dapat diketahui bahwa sub variabel dari marketing communication di Taman Nasional Ujung Kulon yang mendapatkan penilaian paling tinggi yaitu interactive/internet marketing yaitu sebesar 26,63\%, hal ini dikarenakan sebagian besar wisatawan lebih tertarik mencari informasi mengenai Taman Nasional Ujung Kulon melalui internet. Selain itu pada zaman sekarang media internet merupakan media yang penting untuk dimiliki oleh para pekerja pada bidang industri dan jasa dan memungkinkan untuk memiliki perangkat internet sehingga dapat dengan mudah mendapatkan informasi yang dibutuhkan wisatawan.

Sub variabel yang mendapatkan penilaian terendah yaitu Public Relation and Publicity yaitu sebesar $23,62 \%$. Hal ini dikarenakan media identity melalui logo yang dimiliki oleh Taman Nasional Ujung
Kulon kurang menarik bagi para wisatawan. Selain itu Public Relation and Publicity melalui news juga kurang memberikan informasi yang jelas mengenai berita yang terjadi di Taman Nasional Ujung Kulon, sehingga wisatawan tidak dapat mengetahui secara jelas mengenai berita Taman Nasional Ujung Kulon.

\subsection{Rekapitulasi Hasil Tanggapan Wisatawan terhadap Keputusan Berkunjung di Taman Nasional Ujung Kulon \\ Rekapitulasi mengenai hasil tanggapan} wisatawan terhadap keputusan berkunjung di Taman Nasional Ujung Kulondapat dilihat pada tabel 4.2 berikut ini.

TABEL 4.2

REKAPITULASI TANGGAPAN WISATAWAN TERHADAP

KEPUTUSAN BERKUNJUNG DI TAMAN NASIONAL UJUNG KULON

\begin{tabular}{|c|c|c|c|c|}
\hline $\begin{array}{l}\mathrm{N} \\
\mathrm{O}\end{array}$ & Sub Variabel & $\begin{array}{c}\text { Tota } \\
1 \\
\text { Skor }\end{array}$ & $\begin{array}{c}\text { Skor } \\
\text { Rata- } \\
\text { rata }\end{array}$ & $\%$ \\
\hline 1 & $\begin{array}{l}\text { Pemilihan } \\
\text { Produk/Jasa }\end{array}$ & $\begin{array}{c}171 \\
1\end{array}$ & 427,75 & $\begin{array}{c}25,7 \\
3\end{array}$ \\
\hline 2 & $\begin{array}{c}\text { Pemilihan } \\
\text { Merek }\end{array}$ & $\begin{array}{c}126 \\
7\end{array}$ & 422,33 & $\begin{array}{c}25,4 \\
0\end{array}$ \\
\hline 3 & $\begin{array}{c}\text { Pemilihan } \\
\text { Perantara/Salu } \\
\text { ran Pemesanan }\end{array}$ & 827 & 413,5 & $\begin{array}{c}24,8 \\
8\end{array}$ \\
\hline 4 & $\begin{array}{l}\text { Pemilihan } \\
\text { Waktu } \\
\text { Berkunjung }\end{array}$ & $\begin{array}{c}119 \\
6\end{array}$ & 398,67 & $\begin{array}{c}23,9 \\
9\end{array}$ \\
\hline & Total & $\begin{array}{c}5.00 \\
1\end{array}$ & $\begin{array}{c}1662,2 \\
5\end{array}$ & 100 \\
\hline
\end{tabular}

Sumber: Hasil Pengolahan Data 2012

Berdasarkan tabel 4.2 dapat dilihat bahwa sub variabel dari keputusan berkunjung di Eldorado spor club Bandung yang mendapat penilaian tertinggi yaitu pada pemilihan produk sebesar $36,88 \%$. Hal ini dikarenakan setiap pengunjung memiliki kebutuhan olahraga masing-masing tanpa harus terpacu oleh seluruh fasilitas yang disediakan. Sehingga pengunjung lebih selektif menggunakan fasilitas yang disediakan sesuai dengan kebutuuhan pengunjung.

Sedangkan sub variabel yang mendapat penilaian terendah yaitu pemilihan tempat sebesar $14,01 \%$. Hal ini disebabkan karena sebagian besar pengunjung berasal dari daerah pusat kota yang mana jangkauan ke Eldorado sport, cafe, and concert hall 
Bandung sendiri cukup jauh dari pusat kota. bahwa tanggapan responden terhadap keputusan berkunjung di Taman Nasional Ujung Kulon yang mendapatkan penilaian paling tinggi yaitu pemilihan produk/jasa sebesar $25,73 \%$, hal ini dikarenakan jumlah daya tarik wisata yang ada di Taman Nasioanl Ujung Kulon cukup beragam sehingga wisatawan bisa memilih dari beberapa daya tarik wisata yang akan mereka kunjungi. Selain itu, sebagian besar wisatawan tertarik dengan suasana alam yang masih alami seperti Taman Nasional Ujung Kulon.

Penilaian terendah yaitu pemilihan waktu berkunjung sebesar 23,99\%. Hal ini dikarenakan kawasan wisata Taman Nasional Ujung Kulon berlokasi di desa terpencil, jauh dari pusat kota, selain itu untuk mengunjungi Taman Nasional Ujung Kulon harus melihat situasi cuaca yang sedang terjadi, karena dapat mengakibatkan pengalaman wisatawan kurang baik dengan cuaca yang tidak mendukung. Namun sebagian wisatawan mancanegara menyukai cuaca yang ekstrim seperti dalam keadaan ombak yang sedang pasang, karena ingin melakukan surfing.

\subsection{Pengaruh Marketing Communication terhadap Keputusan Berkunjung di Taman Nasional Ujung Kulon}

Pengujian hipotesis ini dilakukan untuk mengetahui besarnya pengaruh program Marketing Communication (X) yang terdiri dari beberapa sub variabel diantaranya Advertising (X1.1), Event and Experience (X1.2), Public Relations and Publicity (X1.3) dan Interactive/Internet Marketing (X1.4) terhadap Keputusan Berkunjung di Taman Nasional Ujung Kulon (Y) yang terdiri dari beberapa sub variabel diantaranya pemilihan produk/jasa (Y1), pemilihan merek (Y2), pemilihan saluran/perantara pemesanan (Y3), dan pemilihan waktu berkunjung (Y4) dilakukan dengan menggunakan uji statistik analisis jalur (path analysis).

Serta untuk menguji hipotesis dihitung besarnya koefisien jalur masing-masing variabel. Selanjutnya berdasarkan perhitungan statistik yang didasarkan pada angka-angka dari masing-masing variabel terlebih dahulu dilakukan transformasi, dimana dalam perhitungan transformasi dilakukan dengan program yang ada dalam SPSS Versi 17.0. Secara lengkap hasil pengolahan data pengaruh program marketing communication beserta 4 sub variabelnya terhadap keputusan berkunjung disajikan secara rinci sebagai berikut.

TABEL 4.3

\section{MATRIKS KORELASI ANTAR SUB VARIABEL MARKETING COMMUNICATION TERHADAP KEPUTUSAN BERKUNJUNG}

\begin{tabular}{|c|c|c|c|c|c|}
\hline & $\begin{array}{c}(\mathrm{Y}) \\
\text { Kepu } \\
\text { tusan } \\
\text { Berk } \\
\text { unjun } \\
\mathrm{g}\end{array}$ & $\begin{array}{l}\text { (X1.1) } \\
\text { Advert } \\
\text { ising }\end{array}$ & $\begin{array}{l}\text { (X1.2) } \\
\text { Event } \\
\text { and } \\
\text { Experi } \\
\text { ence }\end{array}$ & $\begin{array}{c}\text { (X1.3 } \\
\text { ) } \\
\text { Publi } \\
c \\
\text { Relat } \\
\text { ions } \\
\text { and } \\
\text { Publi } \\
\text { city }\end{array}$ & $\begin{array}{c}\text { (X1.4 } \\
\quad) \\
\text { Intera } \\
\text { ctive } \\
\text { Mark } \\
\text { eting }\end{array}$ \\
\hline $\begin{array}{c}\text { (Y) } \\
\text { Keputu } \\
\text { san } \\
\text { Berkunj } \\
\text { ung }\end{array}$ & 1,000 & 0,977 & 0,945 & $\begin{array}{c}0,74 \\
9\end{array}$ & 0,754 \\
\hline $\begin{array}{l}\text { (X1.1) } \\
\text { Adverti } \\
\text { sing }\end{array}$ & 0,977 & 1,000 & 0,918 & $\begin{array}{c}0,83 \\
6\end{array}$ & 0,642 \\
\hline $\begin{array}{l}\text { (X1.2) } \\
\text { Event } \\
\text { and } \\
\text { Experie } \\
\text { nce }\end{array}$ & 0,945 & 0,918 & 1,000 & $\begin{array}{c}0,58 \\
4\end{array}$ & 0,746 \\
\hline $\begin{array}{c}\text { (X1.3) } \\
\text { Public } \\
\text { Relatio } \\
\text { ns and } \\
\text { Publicit } \\
y\end{array}$ & 0,749 & 0,836 & 0,584 & $\begin{array}{c}1,00 \\
0\end{array}$ & 0,308 \\
\hline $\begin{array}{l}\text { (X1.4) } \\
\text { Interact } \\
\text { ive } \\
\text { Marketi } \\
\text { ng }\end{array}$ & 0,754 & 0,642 & 0,746 & $\begin{array}{c}0,30 \\
8\end{array}$ & 1,000 \\
\hline
\end{tabular}

Sumber : Pengolahan Data 2012

Berdasarkan hasil matriks korelasi antar sub variabel menunjukan hubungan setiap sub variabel X dari X1.1, X1.2, X1,3 dan X1.4 dengan Y. Berdasarkan tabel diketahui bahwa nilai hubungan antara sub variabel $\mathrm{X}$ dengan Y secara berurutan yaitu, 
Advertising (0,977), Event and Experience (0,945), Public relatios and publisity $(0,749)$, dan Interactive Marketing (0,754). Variabel yang memiliki hubungan yang terbesar adalah hubungan antara $\mathrm{X}_{1.1}$ dengan Y sebesar 0,977. Hal ini terjadi karena promosi yang dilakukan oleh pihak pengelola Taman Nasional Ujung Kulon lebih banyak melalui advertising seperti media cetak dan media elektronik.

Secara lengkap pengaruh masingmasing Marketing communication terhadap Keputusan Berkunjung dalam Gambar 4.1 berikut ini :

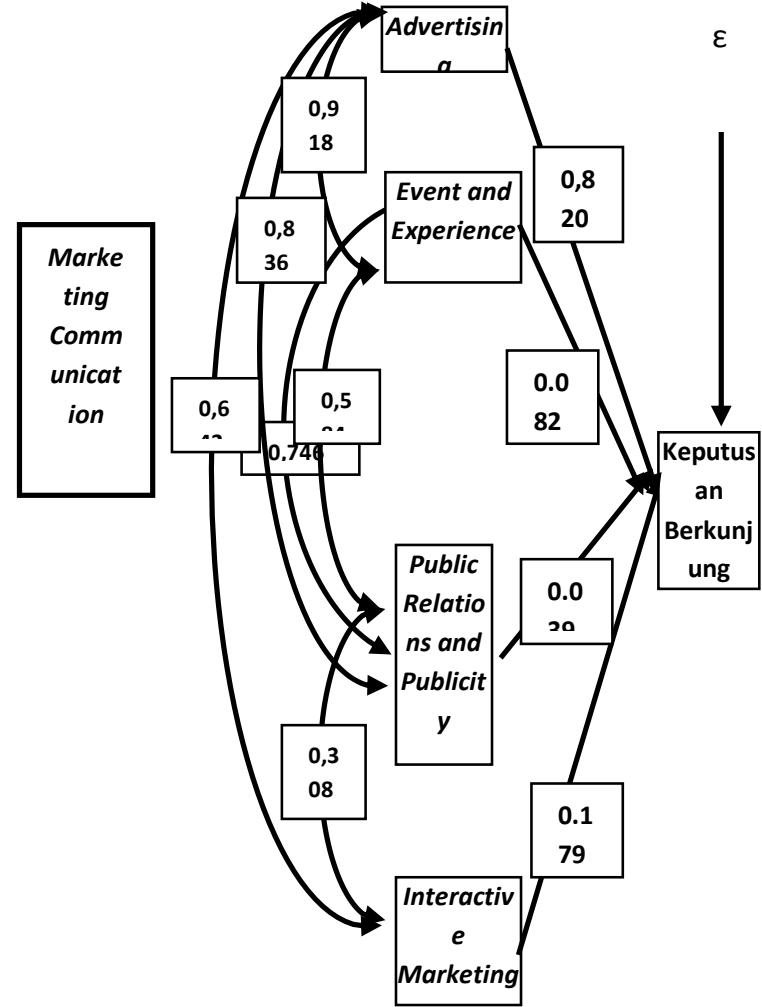

Sumber : Hasil Pengolahan Data 2012

GAMBAR 4.1

DIAGRAM JALUR PENGUJIAN HIPOTESIS $X$ TERHADAP Y

Berdasarkan diagram, jalur pengujian hipotesis pada gambar 4.1 maka dilakukan perhitungan untuk mengetahui pengaruh langsung dan tidak langsung antara dimensidimensi yang sesuai dengan Tabel 4.4 sebagai berikut.

TABEL 4.4

HASIL PENGUJIAN KOEFISIEN JALUR, PENGARUH LANGSUNG DAN TIDAK LANGSUNG MARKETING COMMUNICATION TERHADAP KEPUTUSAN BERKUNJUNG

\begin{tabular}{|c|c|c|c|c|c|c|c|c|c|}
\hline \multirow[b]{2}{*}{$\mathrm{X}$} & \multirow{2}{*}{$\begin{array}{c}\text { Pengaruh } \\
\text { Langsung } \\
\text { Terhadap } \\
\text { Y }\end{array}$} & \multicolumn{4}{|c|}{ Pengaruh Tidak Langsung Melalui } & \multirow{2}{*}{$\mathrm{R}^{2} \mathrm{YX} 1.1 \ldots . \mathrm{X} 1.4$} & \multirow{2}{*}{$\begin{array}{l}\mathrm{t}^{\text {hitung }} \\
\text { ttabel } \\
1,660\end{array}$} & \multirow{2}{*}{ Sig } & \multirow{2}{*}{ Keputusan } \\
\hline & & $\mathrm{X} 1.1$ & $\mathrm{X} 1.2$ & $\mathrm{X} 1.3$ & $\mathrm{X} 1,4$ & & & & \\
\hline $\mathrm{X} 1.1$ & 0,672 & 1 & 0,062 & 0,027 & 0,094 & 0,9 & 9.210 & 0,000 & Ho ditolak \\
\hline $\mathrm{X} 1.2$ & 0,007 & 0,062 & 1 & 0,002 & 0,011 & 0,082 & 1.371 & 0,173 & Ho ditolak \\
\hline $\mathrm{X} 1.3$ & 0,002 & 0,027 & 0,002 & 1 & 0,002 & 0,033 & -883 & 0,379 & Ho Diterima \\
\hline $\mathrm{X} 1.4$ & 0,032 & 0,094 & 0,011 & 0,002 & 1 & 0,139 & 8.984 & 0,000 & Ho ditolak \\
\hline $\mathrm{R} 2$ & & & & & & 1,154 & & & \\
\hline
\end{tabular}

Sumber : Hasil Pengolahan Data 2012

Pengujian hipotesis melalui nilai signifikansi dan uji t menghasilkan tiga penolakan terhadap Ho, karena nilai signifikansi lebih kecil dibandingkan dengan 0.05. hal tersebut berarti bahwa terdapat pengaruh yang signifikan antara marketing communication yang terdiri dari advertising $\left(\mathrm{X}_{1.1}\right)$, event and experience $\left(\mathrm{X}_{1.2}\right)$, dan interactive marketing $\left(\mathrm{X}_{1.4}\right)$ terhadap keputusan berkunjung di Taman Nasional Ujung Kulon. Kredibilitas $\left(\mathrm{X}_{1.3}\right)$ di terima, 
atau dengan kata lain variabel tersebut tidak berpengaruh terhadap keputusan berkunjung. Berdasarkan hasil pengujian hipotesis path analysis tersebut, terdapat satu sub variabel marketing communication yang tidak signifikan yaitu public relations and publicity. Oleh karena itu sub variabel yang tidak signifikan tersebut dihilangkan dalam penghitungan selanjutnya. Metode ini dalam kajian path analysis disebut dengan model trimming yaitu "Deleting one path at a time until a significant chi-square difference indicates trimming has gone too far. A nonsignificant chi-square difference means the researcher should choose the more parsimonious model" (Garson dalam Vita, 2011). Dalam hal ini model trimming dilakukan guna menghindari hasil yang tidak signifikan terhadap sub variabel marketing communication yang disebabkan oleh satu variabel tersebut sehingga data yang diperoleh diolah kembali. Pengujian hipotesis selanjutnya hanya terdiri dari tiga sub variabel yaitu advertising, event and experience dan interactive marketing.

Hasil korelasi antara marketing communication yang terdiri dari advertising $\left(\mathrm{X}_{1.1}\right)$, event and experience $\left(\mathrm{X}_{1.2}\right)$, dan interactive marketing $\left(\mathrm{X}_{1.4}\right)$ dengan menggunakan model trimming disajikan dalam tabel berikut.
TABEL 4.5

MATRIKS KORELASI ANTAR SUB

VARIABEL ADVERTISING, EVENT

AND EXPERIENCE DAN

INTERACTIVE MARKETING TERHADAP KEPUTUSAN

BERKUNJUNG MENGGUNAKAN MODEL TRIMMING

\begin{tabular}{|c|c|c|c|c|}
\hline & $\begin{array}{c}\text { (Y) } \\
\text { Keputus } \\
\text { an } \\
\text { Berkunj } \\
\text { ung }\end{array}$ & $\begin{array}{c}\text { (X1.1) } \\
\text { Advertis } \\
\quad \text { ing }\end{array}$ & $\begin{array}{c}\text { (X1.2) } \\
\text { Event } \\
\text { and } \\
\text { Experie } \\
\text { nce }\end{array}$ & $\begin{array}{c}\text { (X1.4) } \\
\text { Interact } \\
\text { ive } \\
\text { Marketi } \\
\text { ng }\end{array}$ \\
\hline $\begin{array}{c}\text { (Y) } \\
\text { Keputus } \\
\text { an } \\
\text { Berkunj } \\
\text { ung }\end{array}$ & 1,000 & 0,977 & 0,945 & 0,754 \\
\hline $\begin{array}{c}\text { (X1.1) } \\
\text { Advertis } \\
\text { ing }\end{array}$ & 0,977 & 1,000 & 0,918 & 0,642 \\
\hline $\begin{array}{l}\text { (X1.2) } \\
\text { Event } \\
\text { and } \\
\text { Experie } \\
\text { nce }\end{array}$ & 0,945 & 0,918 & 1,000 & 0,746 \\
\hline $\begin{array}{c}\text { (X1.4) } \\
\text { Interacti } \\
\text { ve } \\
\text { Marketi } \\
n g\end{array}$ & 0,754 & 0,642 & 0,746 & 1,000 \\
\hline
\end{tabular}

Sumber : Pengolahan Data, 2012

Berdasarkan hasil matrik korelasi anatar sub variabel marketing communication yaitu advertising, event and experience dan interactive marketing terhadap keputusan berkunjung diperoleh hasil korelasi secara berurutan yaitu, advertising $(0,977)$, event and experience $(0,945)$, dan interactive marketing $(0,754)$. Advertising memperoleh korelasi terbesar, dengan nilai korelasi 0,977. Pengaruh marketing communication terhadap keputusan berkunjung setelah menggunakan model trimming secara lengkap disajikan dalam Gambar 4.2 sebagai berikut: 


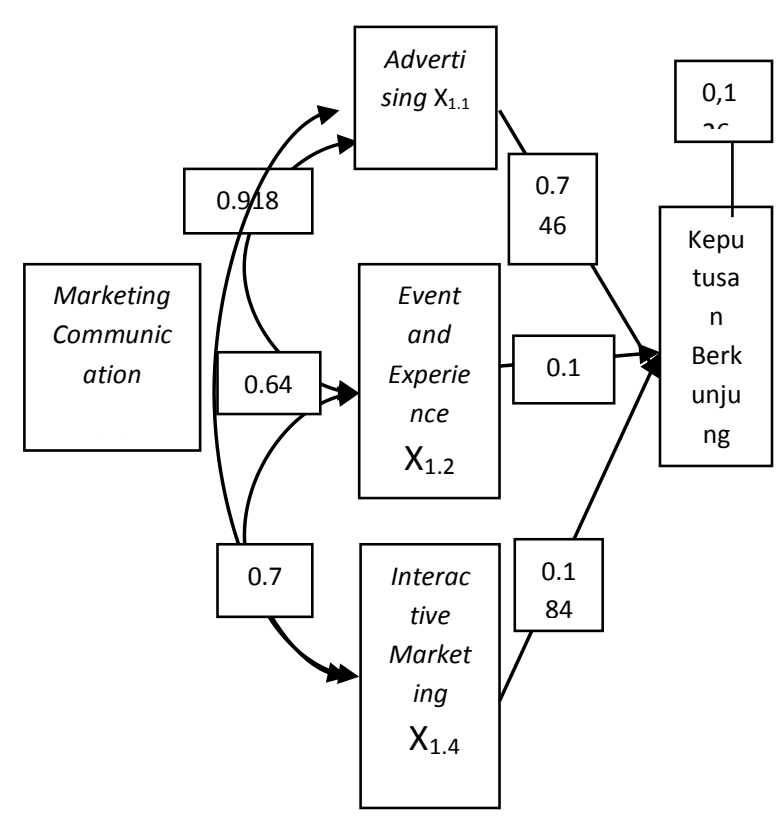

Sumber : Hasil Pengolahan Data, 2012

GAMBAR 4.2

DIAGRAM JALUR PENGUJIAN

HIPOTESIS MARKETING

COMMUNICATION TERHADAP

KEPUTUSAN BERKUNJUNG

MENGGUNAKAN MODEL TRIMMING

Berikut disajikan pengujian koefisien jalur setiap sub variabel marketing communication dan kontribusi secara langsung maupun tidak langsung setiap sub variabel marketing communication terhadap keputusan berkunjung menggunakan model trimming pada Tabel 4.6.

TABEL 4.6

HASIL PENGUJIAN KOEFISIEN JALUR, PENGARUH LANGSUNG DAN

TIDAK LANGSUNG MARKETING

COMMUNICATION TERHADAP KEPUTUSAN BERKUNJUNG MENGGUNAKAN MODEL TRIMMING

\begin{tabular}{|c|c|c|c|c|c|c|c|c|}
\hline \multirow[t]{2}{*}{6} & \multirow{2}{*}{$\begin{array}{c}\text { Peng } \\
\text { aruh } \\
\text { Lang } \\
\text { sung } \\
\text { Terh } \\
\text { adap } \\
\text { Y } \\
\end{array}$} & \multicolumn{3}{|c|}{$\begin{array}{c}\text { Pengaruh Tidak } \\
\text { Langsung } \\
\text { Melalui }\end{array}$} & \multirow{2}{*}{$\begin{array}{c}\mathrm{R}^{2} \\
\text { YX1.1,X } \\
1.2, \mathrm{X} 1.4\end{array}$} & \multirow{2}{*}{$\begin{array}{c}\mathrm{t}^{\text {hitu }} \\
\mathrm{ng} \\
\mathrm{tta} \\
\mathrm{bel} \\
1,6 \\
60\end{array}$} & \multirow[t]{2}{*}{$\begin{array}{c}\mathrm{Si} \\
\mathrm{g}\end{array}$} & \multirow[t]{2}{*}{$\begin{array}{l}\text { Kepu } \\
\text { tusan }\end{array}$} \\
\hline & & $\begin{array}{l}\mathrm{X} \\
1 . \\
1\end{array}$ & $\begin{array}{l}\mathrm{X} \\
1 . \\
2\end{array}$ & $\begin{array}{l}\mathrm{X} \\
1, \\
4\end{array}$ & & & & \\
\hline $\begin{array}{l}\mathrm{X} \\
1 . \\
1\end{array}$ & $\begin{array}{c}0,55 \\
7\end{array}$ & 1 & $\begin{array}{c}0, \\
08 \\
4 \\
\end{array}$ & $\begin{array}{c}0, \\
08 \\
8\end{array}$ & 0,729 & $\begin{array}{c}22, \\
98 \\
5\end{array}$ & $\begin{array}{c}0, \\
00 \\
0\end{array}$ & $\begin{array}{c}\text { Ho } \\
\text { ditola } \\
\mathrm{k}\end{array}$ \\
\hline $\begin{array}{l}\mathrm{X} \\
1 . \\
2\end{array}$ & $\begin{array}{c}0,01 \\
5\end{array}$ & $\begin{array}{c}0, \\
08 \\
4\end{array}$ & 1 & $\begin{array}{c}0, \\
01 \\
7\end{array}$ & 0,116 & $\begin{array}{l}3,2 \\
95\end{array}$ & $\begin{array}{c}0, \\
00 \\
1\end{array}$ & $\begin{array}{c}\text { Ho } \\
\text { ditola } \\
\mathrm{k}\end{array}$ \\
\hline $\begin{array}{l}\mathrm{X} \\
1 . \\
4\end{array}$ & $\begin{array}{c}0,03 \\
4\end{array}$ & $\begin{array}{c}0, \\
08 \\
8 \\
\end{array}$ & $\begin{array}{c}0, \\
01 \\
7 \\
\end{array}$ & 1 & 0,139 & $\begin{array}{c}9,4 \\
80\end{array}$ & $\begin{array}{c}0, \\
00 \\
0\end{array}$ & $\begin{array}{c}\text { Ho } \\
\text { ditola } \\
\mathrm{k} \\
\end{array}$ \\
\hline $\begin{array}{l}\mathrm{R} \\
2\end{array}$ & & & & & 0,984 & & & \\
\hline
\end{tabular}

Sumber : Hasil Pengolahan Data 2012
Pengujian hipotesis melalui nilai signifikansi dan uji-t menghasilkan penolakan terhadap Ho, karena nilai signifikansi lebih kecil dibandingkan 0,05. Hal ini berarti terdapat pengaruh yang signifikan antara marketing communication yang terdiri dari advertising, event and experience dan interactive marketing terhadap keputusan berkunjung di Taman Nasional Ujung Kulon.

Berdasarkan Tabel 4.6 setelah dilakukan proses trimming dapat diketahui bahwa pengaruh marketing communication terhadap keputusan berkunjung adalah sebesar 0,984 sedangkan koefisien jalur variabel lain diluar marketing communication ditentukan melalui:

$$
\begin{aligned}
\mathrm{P} z \varepsilon & =\sqrt{1-R^{2}} Y_{\left(\mathrm{x}_{1}, \mathrm{x}_{2}, \mathrm{x}_{3}\right) .} \\
& =\sqrt{1-0,016} \\
& =0,126
\end{aligned}
$$

Hal tersebut berarti advertising, event and experience, dan interactive marketing mempengaruhi keputusan berkunjung sebesar $98,4 \%$ dan sisanya $1,6 \%$ dipengaruhi oleh faktor lain diluar dari variabel marketing communication yang signifikan, yang tidak masuk kedalam penelitian ini. Berdasarkan hasil pengolahan data menggunakan model trimming pada pengujian path analysis, advertising yang paling tinggi pengaruhnya dalam keputusan berkunjung dengan persentase pengaruh langsung sebesar $55,7 \%$, pengaruh tidak langsung melalui event and experience sebesar $0,8 \%$, dan melalui interactive marketing sebesar $0,8 \%$.

Berdasarkan hasil analisis di atas sesuai dengan gambaran umum mengenai program marketing communicataion (X) yang terdiri dari advertising (X1), event and experinece (X2), dan interactive marketing (X4) terhadap keputusan berkunjung (Y) ternyata cukup efektif dalam memberikan stimulus untuk meningkatkan kunjungan wisatawan di Taman Nasional Ujung Kulon.

\subsection{Implikasi Hasil Temuan Penelitian Temuan Penelitian Bersifat Teoritik}

1. Berdasarkan hasil temuan penelitian penulis memperkuat konsep program marketing communication yang dikemukakan oleh Kotler \& Keller (2009 : 472) bahwa Marketing Communication terdiri dari delapan 
elemen yaitu Advertising, Sales Promotion, Event and experience, Public Relations and publicity, Direct marketing, Interactive marketing, Word-of-mouth marketing dan Personal Selling.

2. Berdasarkan hasil temuan penelitian penulis memperkuat konsep keputusan berkunjung yang dikemukakan oleh Kotler \& Keller (2009 : 248) bahwa keputusan berkunjung terdiri dari beberapa komponen yaitu pemilihan produk/jasa, pemilihan merek/brand, pemilihan perantara, pemilihan waktu berkunjung, dan metode pembayaran.

3. Berdasarkan hasil temuan penelitian penulis memperkuat konsep marketing communication yang dikemukakan oleh Daniel Axelsson dan Hendrik Nordberg (2005) yaitu Marketing Communication message, such as advertising, sales promotion, direct marketing, public relation, special event or trade shows all seek to do are thing, to place bits of information in the consumer's mind, to influence later decision. Yang berarti bahwa pesan marketing communication seperti periklanan, sales promosi, pemasaran langsung, hubungan masyarakat, event spesial atau pertunjukan yang melakukan sesuatu memberikan tempat untuk menginformasikan kepada konsumen dalam mempengaruhi keputusan selanjutnya.

\section{Temuan Penelitian Bersifat Empirik}

1. Terdapat faktor pembentuk program marketing communication yang memiliki empat dimensi secara berurutan adalah advertising, event and experience, public relation and publicity dan interactive marketing. Tetapi setelah diuji, public relation and publicity menunjukkan hasil yang tidak signifikan dan tidak cukup mempengaruhi wisatawan untuk berkunjung karena kesamaannya dengan event and experience sehingga hanya advertising, event and experience, dan interactive marketing saja yang digunakan dalam penelitian ini.

2. Faktor pembentuk keputusan berkunjung di Taman Nasional Ujung Kulon dengan subvariabel advertising, event and experience, dan interactive marketing merupakan faktor yang paling besar berpengaruh pada keputusan berkunjung di Taman Nasional Ujung Kulon.

3. Faktor keputusan berkunjung yang terdiri dari pemilihan produk/jasa, pemilihan merek, pemilihan perantara/saluran pemesanan dan pemilihan waktu berkunjung. Dari indikator-indikator tersebut yang mendapatkan penilaian tertinggi adalah pemilihan produk/jasa.

\section{KESIMPULAN DAN REOMENDASI}

\subsection{Kesimpulan}

Berdasarkan hasil penelitian yang dilakukan oleh peneliti melalui analisis deskriptif dan verfifikatif dengan menggunakan path analysis, maka berdasarkan penelitian tersebut dapat diambil kesimpulan sebagai berikut:

1. Dari empat subvariabel marketing communication yang diteliti yaitu advertising, event and experience, public relation and publicity dan interactive marketing menerangkan gambaran pada subvariabel interactive marketing memiliki tanggapan yang lebih tinggi dibandingkan dengan aspek lainnya. Adapun subvariabel public relation and publicity memiliki tanggapan yang lebih rendah di Taman Nasional Ujung Kulon. Hal ini dikarenakan para wisatawan lebih sering menggunakan internet dalam mencari informasi mengenai Taman Nasional Ujung Kulon, selain lebih mudah dan praktis media internet pada zaman sekarang sudah merupakan media yang memiliki peranan penting bagi sebagian besar orang sehingga para wisatawan lebih tertarik untuk menggunakan internet serta memberikan tanggapan lebih tinggi pada interactive marketing, sedangkan tanggapan lebih rendah mengenai public relation and publicity dikarenakan media identity berupa logo yang dimiliki Taman Nasional Ujung Kulon kurang menarik bagi para wisatawan.

2. Gambaran mengenai keputusan berkunjung wisatawan ke Taman Nasional Ujung Kulon berdasarkan subvariabel yang terdiri dari pemilihan produk/jasa, pemilihan merek, pemilihan perantara/saluran pemesanan 
dan pemilihan waktu berkunjung menunjukan bahwa pemilihan produk/jasa memiliki tanggapan yang lebih tinggi sedangkan pemilihan waktu berkunjung memiliki tanggapan yang lebih rendah. Hal ini dikarenakan jumlah produk/jasa yang ditawarkan oleh Taman Nasional Ujung Kulon cukup beragam. Selain memiliki beragam jumlah daya tarik wisata seperti pulau peucang, pulau handeleum dan pulau panaitan, serta banyak atraksi wisata yang dapat dilakukan seperti snorkling, tracking, surfing, canoeing. Untuk tanggapan lebih rendah yaitu dalam hal pemilihan waktu berkunjung. Ini dikarenakan lokasi Taman Nasional Ujung Kulon yang berada di desa terpencil, selain itu harus memilih cuaca yang tepat dalam berkunjung, serta pembatasan jumlah dan waktu kunjungan.

3. Pengaruh program marketing communication terhadap keputusan berkunjung menunjukan nilai yang signifikan. Artinya marketing communication yang terdiri dari: advertising, event and experience, dan interactive marketing memberikan pengaruh yang kuat terhadap keputusan berkunjung di Taman Nasional Ujung Kulon, sedangkan subvariabel public relation and publicity tidak menunjukan nilai yang signifikan maka dari itu subvariabel tersebut dihilangkan. Dalam hal ini yang memiliki pengaruh paling tinggi adalah advertising karena merupakan alat promosi yang memiliki berbagai media seperti media cetak dan media elektronik sehingga memudahkan para wisatawan untuk mengenal lebih jauh mengenai objek wisata, sedangkan event and experience memiliki pengaruh yang lebih rendah karena event yang diselenggarakan oleh Taman Nasional hanya berbentuk pameran, namun terlepas dari semua itu secara keseluruhan program marketing communication memiliki pengaruh yang kuat untuk memutuskan wisatawan dalam berkunjung ke Taman Nasional Ujung Kulon. Dengan demikian, apabila terjadi peningkatan kunjungan dalam pelaksanaan program marketing communication di suatu kawasan wisata maka dapat memperkuat keputusan berkunjung di Taman Nasional Ujung Kulon.

\subsection{Rekomendasi}

Berdasarkan hasil penelitian yang telah dilakukan, maka penulis merekomendasikan hal-hal sebagai berikut:

1. Pada variabel marketing communication menunjukan bahwa subvariabel event and experience memiliki pengaruh lebih rendah dibandingkan dengan subvariabel lainnya. Dengan demikian pengelola Taman Nasional Ujung Kulon perlu memberbaiki dalam event yang diselenggarakan. Seperti memberikan informasi yang lebih jelas mengenai pameran yang diselenggrakan dan memberikan gambaran yang lebih lengkap mengenai Taman Nasional Ujung Kulon. Selain itu perlu menambah program promosi dalam aspek event and experience yang dapat memberikan pengalaman tidak terlupakan pada wisatawan.

2. Berdasarkan tanggapan mengenai keputusan berkunjung di Taman Nasional Ujung Kulon menunjukan bahwa pemilihan waktu berkunjung merupakan aspek yang memiliki tanggapan paling rendah dibandingkan dengan aspek lainnya. Dengan demikian pengelola Taman Nasional Ujung Kulon perlu memberikan informasi mengenai waktu kunjungan terbaik kepada para wisatawan, seperti membuat jadwal waktu kunjungan terbaik yang dapat di informasikan kepada para wisatawan melalui berbagai media seperti melalui internet, brosur, booklet, dan program lainnya sehingga para wisatawan dapat mengetahui waktu kunjungan terbaik dan mendapatkan pengalaman tak terlupakan setelah berkunjung ke Taman Nasional Ujung Kulon.

\section{DAFTAR PUSTAKA}

Ali Hasan. (2009). Marketing Edisi Baru. Yogyakarta: Media Pressindo.

Belch, G.E., \& Belch, M.A. (2007). Advertising and Promotion. New York: McGraw-Hill, Inc.

Birger, Wernerfelt. (2007). Efficient Marketing Communication: Helping the Customer Learn. Journal of Marketing Research, Vol. 33, No. 2.

Copley, Paul. (2004). Marketing Communication Management. London: ELSEVIER 
Dinas Budaya dan Pariwisata Provinsi Banten. (2010). Neraca Satelit Pariwisata Banten 2009. Banten: Disbudpar

Fandy, Tjiptono. (2007). Pemasaran Jasa. Malang: Bayumedia

Fill, Chris. (1999). Marketingg Communication, Contexts, Contents and Strategies Second edition. Singapore: Prectice hall

Hackley, Crish. (2005). Advertising and Promotions. London: SAGE.

Harun Al Rasyid. (1994). Teknik Penarikan Sampel dan Penyusunan Skala. Bandung: Program Studi Ilmu Sosial Bidang Kajian Utama Sosiologi Antropologi Program Pasca Sarjana UNPAD

Husein Umar. (2009). Metode Penelitian Untuk Skripsi dan Tesis Bisnis Edisi Kedua. Jakarta: Rajawali Pers.

Ismayanti. (2010). Pengantar Pariwisata. Jakarta: Grasindo.

Kennedy, John E. (2010). Marketing Communication : Teknik \& Strategi. Bhuana Ilmu Populer.

Komalasari, Lala. (2011). Pengembangan Produk Wisata Pantai Pangandaran Pasca Tsunami Dalam Upaya Meningkatkan Kunjungan Wisatawan di Pantai Pangandaran. Skripsi Sarjana pada FPIPS UPI Bandung: tidak diterbitkan

Kotler, Philip and Amstrong. (2008). Manajemen Pemasaran. Jakarta: PT Indeks.

- Prinsip-prinsip Dasar
Pemasaran Jilid II. Jakarta: Erlangga

Kotler, Bowen and Makens. (2009). Marketing for Hospitality and Tourism 5th edition. New Jersey: Pearson Prentice Hall

Kotler, Philip and Keller Kevin Lane. (2009). Marketing Management 13th edition. New Jersey: Prentice Hall

Laporan Review Zonasi TN Ujung Kulon. (2008). PT Graha Inforesindo

Lovelock, Christopher dan Lauren W (2007). Diterjemahkan oleh Mario Samosir. Manajemen Pemasaran Jasa. Jakarta

Maruapey, Azis, (2000). Konsep dan Pengelolaan Ekowisata. (Online). Tersedia: http//:www.ekowisata.info. (10 Januari 2012)
Morrison, Allistair. (2006). Hospitality and Tourism Marketing 2nd edition. New York: DELMAR

Nadia, Astriani.(2009). Penerapan Konsep Ekowisata pada Taman Nasional Gede-Pangrango. (Online). Tersedia: http://

pipitkecilku.blogdrive.com/archive/9 9.html.(10 Januari 2012)

Philiph, Patrick. (2004). IMC a Primer. Newyork: Routledge

Pomering, Alan. (2009). Sustainable Tourism Marketing :What Should be in the mix . University of Wollongong Australia

Poul, Houman Andersen. (2001). Relationship development and marketing communication: an integrative model. JOURNAL OF BUSINESS \& INDUSTRIAL MARKETING. VOL 16, NO. 3

Ratih, Hurriyati. 2010. Bauran Pemasaran dan Loyalitas Konsumen. Bandung: CV. Alfabeta.

Septiani, Shela Dwi. (2011). Pengaruh Atribut Kawasan Wisata Sanur Bali Terhadap Kepuasan Wisatawan Mancanegara. Skripsi Sarjana pada FPIPS UPI Bandung: tidak diterbitkan

Strauss, Judy and Raymond Frost. (2009). EMarketing, London: Prentice hall

Suharsimi, Arikunto. (2009). Prosedur penelitian: Suatu pendekatan praktek (edisi revisi 5). Jakarta: PT. Rineka Cipta.

Sugiyono. (2008). Statistik Untuk Penelitian. Bandung: Alfabeta.

Suwantoro. (2004). Dasar-dasar Pariwisata. Yogyakarta: Andi

Teguh, Frans. (2010). Tata Kelola Destinasi Pariwisata Berbasis Nilai : Telaah Teoritis dan Implementatif Konsep Destination Management Organization di Indonesia. (Online).Tersedia:http://dmoindonesi $\underline{\text { a.com}} /$ ? module $=$ detailartikel $\& \mathrm{id}=4$ (06 Januari 2012)

Universitas Pendidikan Indonesia. (2011). Pedoman Penulisan Karya Ilmiah. Bandung: UPI Press 
